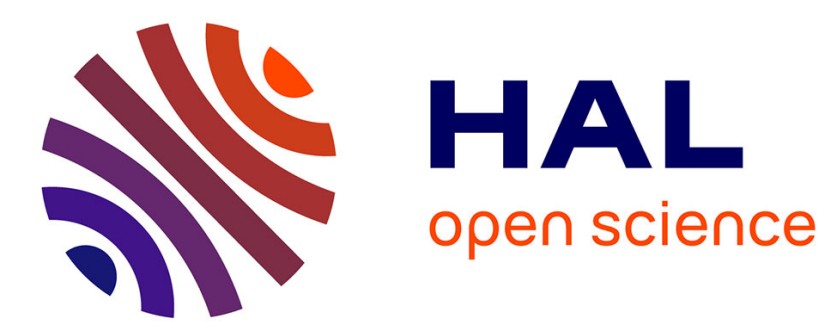

\title{
Magnetic Properties of Barium Ferrite Particles with Fe3O4 Overcoat
}

\author{
I.-C. Tung, L. Perng, T. Chin, C. Lin
}

\section{To cite this version:}

I.-C. Tung, L. Perng, T. Chin, C. Lin. Magnetic Properties of Barium Ferrite Particles with Fe3O4 Overcoat. Journal de Physique IV Proceedings, 1997, 07 (C1), pp.C1-745-C1-746. 10.1051/jp4:19971304 . jpa-00255071

\section{HAL Id: jpa-00255071 https://hal.science/jpa-00255071}

Submitted on 1 Jan 1997

HAL is a multi-disciplinary open access archive for the deposit and dissemination of scientific research documents, whether they are published or not. The documents may come from teaching and research institutions in France or abroad, or from public or private research centers.
L'archive ouverte pluridisciplinaire HAL, est destinée au dépôt et à la diffusion de documents scientifiques de niveau recherche, publiés ou non, émanant des établissements d'enseignement et de recherche français ou étrangers, des laboratoires publics ou privés. 


\title{
Magnetic Properties of Barium Ferrite Particles with $\mathrm{Fe}_{3} \mathrm{O}_{4}$ Overcoat
}

\author{
I.-C. Tung, L.H. Perng*, T.S. Chin and C.H. Lin \\ Department of Materials Science and Engineering, National Tsing Hua University, Hsinchu 30043, \\ Taiwan, China \\ * Department of Chemical Engineering, Ta Hwa College of Technology and Commerce, Chung-Li, \\ Hsinchu, Taiwan, China
}

\begin{abstract}
Superparamagnetic $\mathrm{Fe}_{3} \mathrm{O}_{4}$ fine particles were introduced onto the surface of barium ferrite particles. The method was to coat the barium ferrite particles with a mixed solution of $\mathrm{Fe}^{3+}$ and $\mathrm{Fe}^{2+}$ first at certain concentrations, followed by addition of $\mathrm{NaOH}_{(a(1)}$. The results showed that the coercivity of barium ferrite could be lowered greatly while a high saturation magnetization value was sustained. It indicates that there exists an interaction between barium ferrite and $\mathrm{Fe}_{3} \mathrm{O}_{4}$ fine particlesand this interaction is a matter of interface and may not bear dependency on whether chemical bonding is formed between them.
\end{abstract}

\section{INTRODUCTION}

In recent years there has been growing industrial and academic interest in the development of barium ferrite (BF) due to its potential application in high density magnetic recording. For this application, much effort has been paid upon doping $\mathrm{Ti}$, Co, $\mathrm{Mn}$....etc. into BF to reduce its coercivity $(H \mathrm{c})$, however at the expense of lowering greatly the saturation magnetization $\left(\sigma_{\mathrm{s}}\right)$. Surface coating on BF particles with $\mathrm{Fe}_{3} \mathrm{O}_{4}$ formed by the precipitation method[1], which has a high $\sigma_{\mathrm{s}}(69 \mathrm{emu} / \mathrm{g})$, is highly potential to reduce $\mathrm{HC}$. The surface modification of $\mathrm{BF}$ particles by the formation of a $\mathrm{Fe}_{3} \mathrm{O}_{4}$ epitaxial layer has been tried by Kiyama et al. and Sadamura et al.[2,3] As reported for the modified BF particles, their coercivities decreased and magnetizations increased with the incorporation of $\mathrm{Fe}_{3} \mathrm{O}_{4}$ layers. In this work, we tried to introduce directly the fine $\mathrm{Fe}_{3} \mathrm{O}_{4}$ particles onto the surface of the BF particles.

\section{EXPERIMENTAL}

Barium ferrite particles were firstly prepared by a salt-melt method according to our previous work [4]. They were typically hexagonal platelets with sizes $60-500 \mathrm{~mm}$.

Superparamagnetic $\mathrm{Fe}_{3} \mathrm{O}_{4}$ fine particles were prepared in sequence by preparing a solution of $\mathrm{FeCl}_{3} \cdot 6 \mathrm{H}_{2} \mathrm{O}$ and $\mathrm{FeCl}_{2} \cdot 4 \mathrm{H}_{2} \mathrm{O}$ at a $[\mathrm{Fe} 3+] /[\mathrm{Fe} 2+]$ molar ratio of 1.98 , coprecipitating by adding a $\mathrm{NaOH}$ solution with a molar amount equivalent to 4 times that of total cations in the solution, washing with deionized water, filtering and drying at $100^{\circ} \mathrm{C}$.

$\mathrm{Fe}_{3} \mathrm{O}_{4}$ coated $\mathrm{BF}$ was prepared by adding $\mathrm{BF}$ powders into the solution with the $\left[\mathrm{Fe}^{3+}\right] /\left[\mathrm{Fe}^{2+}\right]$ molar ratio of 1.98 , with various concentrations, viz. $\left[\mathrm{Fe}^{3+}\right]=2,5,7 \mathrm{M}$, taking $\mathrm{BF}$ particles out of the solution by a magnet enclosed by a thin $\mathrm{PVC}$ film, dipping the particles in a $2.5 \mathrm{M} \mathrm{NaOH}_{(\text {aq })}$ by taking the magnet awvay from the film, washing with deonized water, filtering and drying $100^{\circ} \mathrm{C}$.

The crystal structure was identified by X-ray diffractometry (XRD) using CuK $\alpha$ radiation. The particle inorphology was examined by a transmission electron microscope (TEM). The magnetic properties were measured using a vibratingsample magnetometer (VSM) with a maximum field of $2 \mathrm{~T}$ at room temperature.

\section{RESULTS AND DISCUSSION}

In Fig. 1, the diffraction patterns show that pure barium ferrite and $\mathrm{Fe}_{3} \mathrm{O}_{4}$ were obtained. Their magnetic properties are listed in Table 1. It is seen that the $\mathrm{Fe}_{3} \mathrm{O}_{4}$ particles are superparamagnetic. When these $\mathrm{Fe}_{3} \mathrm{O}_{4}$ fine particles move close to the 


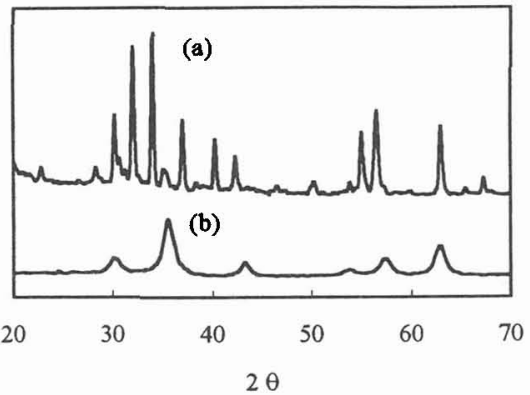

Fig. 1 XRD patterns of barium ferrite (a) and $\mathrm{Fe}_{3} \mathrm{O}_{4}$ (b)

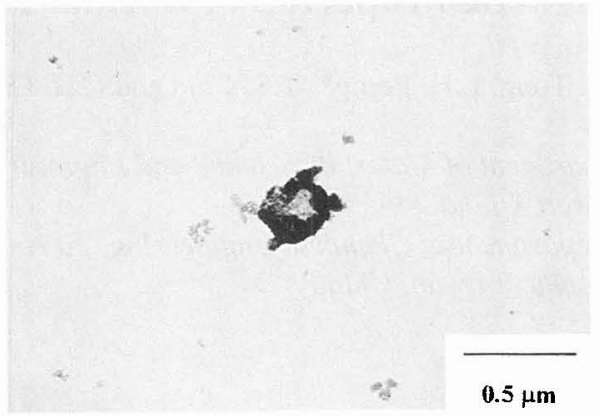

Fig. 2 The particle morphology of the surface coated BF

surface of BF, they would be magnetized and attracted onto the BF surface under magnetic field of the BF particles. Thus, if the surface of $\mathrm{BF}$ is coated with the mixed solution of $\mathrm{Fe}^{3+}$ and $\mathrm{Fe}^{2+}$ first, after addition of $\mathrm{NaOH}_{(\mathrm{ag})}, \mathrm{Fe}_{3} \mathrm{O}_{4}$ fine particles are then expected to form and adhere onto the surface of $\mathrm{BF}$. With this approach, the $\mathrm{BF}$ surface coated with $\mathrm{Fe}_{3} \mathrm{O}_{4}$ particles were fabricated and their magnetic properties are listed in Table 2 . It is seen that the coercivity decreases with coating concentration of the mixed $\mathrm{Fe}^{3+}$ and $\mathrm{Fe}^{2+}$ solution while, however, the magnetization remains at a high value. It thus indicates that there exists an obvious interaction between the $\mathrm{BF}$ and $\mathrm{Fe}_{3} \mathrm{O}_{4}$ particles thereon. Since there is seldom possibility that strong chemical bonding at the interface between the $\mathrm{BF}$ and $\mathrm{Fe}_{3} \mathrm{O}_{4}$ particles can be formed by the low temperature process we adopted, the lowering of coercivity is a matter of interface interaction which leads to strong magnetic coupling.

Table 1. Magnetic properties of barium ferrite and $\mathrm{Fe}_{3} \mathrm{O}_{4}$

\begin{tabular}{cccc}
\hline Materials & $\sigma_{\mathrm{s}}(\mathrm{emu} / \mathrm{g})$ & $\sigma_{\mathrm{r}}(\mathrm{emu} / \mathrm{g})$ & $\mathrm{Hc}(\mathrm{Oe})$ \\
\hline Barium ferrite & 70.3 & 35.3 & 3400 \\
$\mathrm{Fe}_{3} \mathrm{O}_{4}$ & 62.2 & 0 & 0 \\
\hline
\end{tabular}

Table 2. Magnetic properties of surface coated barium ferrite

\begin{tabular}{cccc}
\hline Sample & $\sigma_{s}(\mathrm{emu} / \mathrm{g})$ & $\sigma_{\mathrm{r}}(\mathrm{emu} / \mathrm{g})$ & Hc (Oe) \\
\hline$\left[\mathrm{Fe}^{3+}\right]=2 M$ & 61.7 & 27.3 & 2910 \\
{$\left[\mathrm{Fe}^{3+}\right]=5 M$} & 56.8 & 22.2 & 2520 \\
{$\left[\mathrm{Fe}^{3+}\right]=7 M$} & 58.9 & 23.6 & 1470 \\
\hline
\end{tabular}

The morphology of the surface coated $\mathrm{BF}$ with the $\mathrm{Fe}_{3} \mathrm{O}_{4}$ fine particles is shown in Fig. 2. It can be seen that there is a thin layer of $\mathrm{Fe}_{3} \mathrm{O}_{4}$ covering the surface of $\mathrm{BF}$.

For the surface coated $\mathrm{BF}$ with the solution of $\left[\mathrm{Fe}^{3+}\right]=5 \mathrm{M}$, referring to Table 2, its $\sigma_{\mathrm{s}}$ was $56.8 \mathrm{emu} / \mathrm{g}$ and $H \mathrm{c} 2520$ Oe, while after a heat treatment at $300^{\circ} \mathrm{C}$ for $5 \mathrm{~h}$ its $\sigma_{3}$ was measured to increase to 63.5 and $H \mathrm{c}$ remained the same. Since $\sigma_{s}$ of the superparamagnetic $\mathrm{Fe}_{3} \mathrm{O}_{4}$ increased to $69.5 \mathrm{emu} / \mathrm{g}$ after the same heat treatment, the increase in $\sigma_{\mathbf{s}}$ for the surface coated $\mathrm{BF}$ may be due to the fact that the amorphous $\mathrm{Fe}-\mathrm{O}$ or $\mathrm{FeOOH}$ phase which is present before the heat treatment but crystallizes after the heat treatment. The heat treatment at $300^{\circ} \mathrm{C}$ may induce certain degree of chemical reaction at the interface between the $\mathrm{BF}$ and $\mathrm{Fe}_{3} \mathrm{O}_{4}$ particles, however, its coercivity remains the same. This fact depicts that the increase in coercivity caused by the magnetic coupling may not bear dependency on whether chemical bonding is formed.

\section{Acknowledgments}

This work was sponsored by the National Science Council of the Republic of China under grant NSC 85-2216-E-233-001.

\section{References}

[1] Chikazumi S., Physics of Magnetism (Wiley, New York, 1964) pp. 554.

[2] Kiyarna M., Honmyo T., Nakayama N. and Shinjo T., J. Solid State Chem. 99 (1992) 329-335.

[3] Sadamura H., Sugita N., Maekawa M. and Nagai N., J. Appl. Phys. 75 (1994) 5559-5561.

[4] Chin T. S., Hsu S. L. and Deng M. C., J. Magn. Magn. Mater. 35 (1993) 64-68. 